\title{
Operating and Financial Equilibrium: A Perfect Solution for Price Output Determination Irrespective of Competition
}

\section{Chandra RS* and Banana K}

Department of Commerce and Business Administration, Acharya Nagarjuna University, Guntur, Andhra Pradesh, India

\begin{abstract}
The optimization of profits and profitability of a product or firm depends on the perfectness in arriving at the equilibrium among the costs, price and volume of product(s) of a business. As the volume and price of product are inter related and they are commonly decided in correlation. The profit and profitability depends on costs and cost implications apart from the price and the volume. The price and costs may not be perfect constant and subject to changes in accordance with changes in internal and external environments. The basic and most important decision of every organization is the planning for profits and profitability. The determinants of profits are the costs price and the volume. Hence the core factors in planning for profits are a decision on price and the volume inconsideration of costs and cost functions apart from economic environment implications. Therefore, perfection in planning for profits is subject to finding a perfect equilibrium among the three factors i.e., the price, costs and the volume in accordance with the economic environment implications. Theoretically the economic analysis explained the point of equilibrium as MR=MC i.e., the point or volume of output and the price at which the additional (marginal/variable cost) costs are exactly equal with the marginal revenues (marginal price) and the MC curve should intersect the MR curve from below subject to the condition that there is no change in fixed costs and the investment outlay. In practice, the BEA is serving the purpose. Due to the compulsion of assumptions, it is suffering from inflexibility and imperfection. Though the BEA featured of ensuring direct relation among the costs prices and volume, it is not in a position to give perfect answers for economic environmental implications of "what if". In the light of this it is felt that addition of the feature of flexibility enable to answer the queries of 'what if' and it became the most reliable and simple analysis and a perfect profit planning technique. This research is projected in this direction.
\end{abstract}

Keywords: Financial Equilibrium; Profitability; Price output

\section{Introduction}

The primary aim of every organization is to maximize the efficiency of operations and ensure the attainment of earnings attainable at the maximum efficiency and effectiveness. Further every organization tires to maximize the rate of returns on investments through optimizing the profitability (rate of returns) on sales [1]. The optimization or maximization of profits and the profitability depends on effectiveness of decision on price and volume apart from controlling the costs. The costs, price and the volume are not constant values they tend to vary according to the changes in economic environments both internal and external. The systems of analysis available to provide the assessment of effects of environment in determining the corresponding maximum possible levels of efficiency and effectiveness of operations and planning for profits accordingly are the theoretical frame work of managerial economic analysis proposed equilibrium price and output determination and a partial application in practice is the Breakeven analysis.

The economic analysis though effective in theory it has no perfect practical analytical mechanism for applications in business. The Breakeven analysis though able to provide the basic analysis, it is suffering from inflexibility in analysis with the assumptions of consistency of values as against the needs of considering different values under changing effects of environment at various stages or levels of operations for accuracy. As the breakeven analysis works with all the three variables i.e. price, costs and volume on one hand and the simplicity in analysis and having no other system for the purpose, though it is suffering from laxity of flexibility in giving due consideration for the changing environment impacts in analysis, it has a wide spread use in practice.

The reality is effectiveness in assessment of the environment changes and giving due consideration in analysis for their effects on the determinants i.e. price, volume and costs for assessment of corresponding maximum points of operating efficiency, financial effectiveness and arriving at the relative maximum/optimum rate of returns and the profitability is vital in planning [2]. Such analysis bridges the gap between desired level of profits and the profitability attainable under predicted changes in environments.

This research is projected to ensure the BEA as a compact tool for not only planning for profits but also a guiding instrument for management and control of the profits and profitability with the addition of the flavor of enough flexibility. This ensured the BEA as a practical application tool for the theoretical economic equilibrium, ensuring the optimization of profits and profitability.

\section{Need for the study}

Ensuring the much-needed flexibility and consideration of varying values of variable in progress of operations in accordance with economic environmental implications instead of assumed consistency of values of price, volume and costs for all through the period and ensuring the BEA more realistic.

*Corresponding author: Chandra RS, Research Scholar, Department of Commerce and Business Administration, Acharya Nagarjuna University, Guntur, Andhra Pradesh, India, Tel: 9581205551; E-mail: rcs19661@gmail.com

Received June 12, 2017; Accepted August 24, 2017; Published September 04 2017

Citation: Chandra RS, Banana K (2017) Operating and Financial Equilibrium: A Perfect Solution for Price Output Determination Irrespective of Competition. J Bus Fin Aff 6: 284. doi: 10.4172/2167-0234.1000284

Copyright: (c) 2017 Chandra RS, et al. This is an open-access article distributed under the terms of the Creative Commons Attribution License, which permits unrestricted use, distribution, and reproduction in any medium, provided the original author and source are credited. 


\section{Acronyms}

Average rate of profit or rate of return on sales (ROS or AORS), rate of return on investment (ROI), rate of return on equity after interest but before tax (ROIAIBT), Return on equity or rate of return on equity after interest \&taxes or average rate of return on equity (ROE/ROEAIT), marginal rate of return on sales (MROS or MRROS), marginal rate of return on equity (MRROE/MROE), operating equilibrium, financial equilibrium, investment turnover ratio (ITR), debt to investment Ratio (DIR/DTIR), equilibrium price and output determination. Further sales (Ss), variable cost (V/VC), selling price (SP), fixed cost (F), contribution (C), contribution ratio or PV Ratio (C/S), breakeven point (BEP), BEP Ratio(BEP/S), SMS ratio (SMS/S), weighted average cost of debt (WACOD), cumulative sales (CUMS), cumulative variable cost (CUMV), rate of profit on sales (ROS), ate of profit on investment (ROI), rate of profit on equity (ROE).

\section{Research gap}

From no flexibility state to optimal flexibility state of values of variables in BEA and ensuring the optimization of effectiveness of assumptions of breakeven analysis by limiting the scope of assumptions to the realistic levels in intervals. The breakeven analysis adoptable with changes in values of variables viz Price, costs, volume, investment and the capital structure in accordance with the practical market/economic environments for planning and control of profit [3]. A perfect integration of operating leverage and the financial leverages analysis through break even.

\section{Objectives}

1. Basically, proving that the equilibrium price and output determination of economic theory has enough implications for application in financial analysis and possible to derive a practical analytical tool.

2. Ensuring the breakeven analysis as the core technique in deriving the desired methodical extensions for expanding the analysis from planning for profits to profitability planning through the determination of operating and financial equilibrium with needed flexibility.

3. Unlike the conventional BEA marked for planning for profits, this is to ensure BEA as a perfect tool of scientific application for decisions on financial and operating leverage and profitability planning through the comparative analysis of risk and profitability using the rate of returns on investment and equity with and without debt.

\section{Limitations of the study}

Used a hypothetical example and no real-time data due to the extensive implications of covering the entire spare of variables that affect the profits and profitability under the dynamic conditions of the environment and the objective is to prove that it is possible to determine the equilibrium in practice under the financial analysis.

\section{Research Methodology}

Pure research leads to the discovery of a new theory/result in the development or refinement of a theory that already exists. Basic research projected on innovative methodical and formularize formulations for advanced application in breakeven analysis.

\section{Literature review}

As the concept of the paper is to formulate the calculations innovatively, the common existing formulae were collected from the review of literature:

1. The concepts used in BEA.

2. Sales (S): sales or selling price.

3. Variable costs (V): unit cost/proportional variable total cost.

4. Fixed costs (F): total fixed cost irrespective of level of output.

5. Contribution margin: it is the amount calculated with the following: $\mathrm{C}=\mathrm{S}-\mathrm{V}$

6. P/V Ratio (Profit Volume ratio) it is the ratio of between the contribution and sales.

7. P/V Ratio: $\mathrm{C} / \mathrm{S}^{\star} 100$ i.e. contribution/sales ${ }^{\star} 100$

8. All formulas of BEA ring aground the following equation: $\mathrm{S}-\mathrm{V}=\mathrm{C}=\mathrm{F}+\mathrm{P}$

Existing Other Formulas in Breakeven Analysis for Profit Planning Calculation: Ratio.

Breakeven Point (BEP) I units: F/Cpu in sales value/revenue: $\mathrm{F} / \mathrm{p} / \mathrm{v}$

Determination of sales required to get a profit of Rs. P Required sales \{in units\}: $F+$ desired $P$ Cpu Required sales \{in revenue\}: $F+$ desired $\mathrm{P} / \mathrm{PV}$ Ratio A mount of profit $(\mathrm{P})$ when sales are $\mathrm{S}$ units: $\mathrm{P}=(\mathrm{S} \times \mathrm{Cpu})-\mathrm{F}$

Amount of profit $(\mathrm{P})$ when target sales are ' $\mathrm{S}$ ' rupees: $\mathrm{P}=(\mathrm{S} \times \mathrm{P} / \mathrm{V}$ Ratio)-F

Calculation of safety margin sales SM/MS/SMS: SMS=TS-BEP (in units or value)

SMS in units: $\mathrm{P} / \mathrm{Cpu}, \mathrm{SMS}$ in value: $\mathrm{P} /(\mathrm{P} / \mathrm{V}$ Ratio)

Generally accessible from any text book of cost and management accounting and drawn from the references.

\section{The conventional linear and theoretical models}

The following Summary of the Conventional Linear and Theoretical Models adopted for the citation given here under http://maaw.info/Chapter11.htm

Graphic summaries of the two models are presented in Figures 1 and 2. In the linear model there is one break-even point (BEP) where total revenue is equal to total cost. Since the total revenue and total cost functions are linear, the profit function is also linear. This is because the slope of the profit function is equal to contribution margin per unit which is automatically constant when the sales price and variable cost per unit are constant.

Summary of the theoretical non-linear models: The theoretical model summarized in Figure 2 conveys a very different picture. There are two break-even points where total revenue and total cost are equal. The theoretical profit function intersects the horizontal axis at the two break-even points and reaches a maximum level at the point where the vertical distance between TR and TC is the greatest. In the linear model illustrated in Figure 1, the area to the left of the break-even point represents a loss area and the area to the right of this point represents a profit area that continuously grows larger as additional units are produced and sold. In the linear model, the company maximizes profit where production and sales are at maximum capacity. However, in the theoretical model, there are two loss areas, one to the left of the first $\mathrm{BEP}$ and one to the right of the second BEP. The profit area is between 


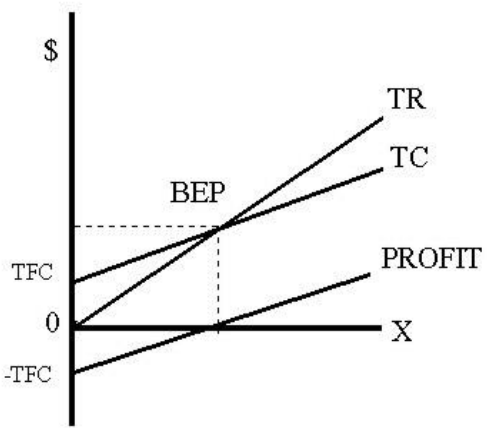

$\mathrm{TR}=$ Total Revenue

$\mathrm{TC}=$ Total Cost

$\mathrm{TFC}=$ Total Fixed Cost

$\mathrm{BEP}=$ Break Even Point

Figure 1: Conventional linear CVP analysis.

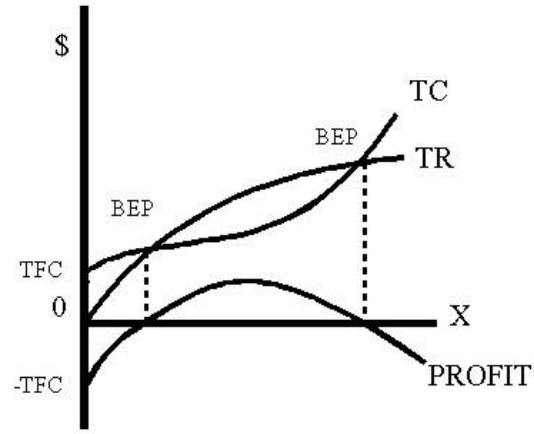

$\mathrm{TR}=$ Total Revenue

$\mathrm{TC}=$ Total Cost

$\mathrm{TFC}=$ Total Fixed Cost

$\mathrm{BEP}=$ Break Even Points

Figure 2: Theoretical CVP analysis.

the two break-even points, thus trying to achieve the maximum level of production and sales will produce losses rather than increased profits. For this reason, some critics of the conventional linear model argue that it represents a naive and dangerous view of a firm's economic environment $[4,5]$. On the other hand, advocates of the linear model contend that short term planning does not require a theoretical model of the entire range of production possibilities. Although the concepts underlying the theoretical model are important, the model does not provide a practical approach for short term planning. However, the linear model is a practical and adequate alternative for planning within the normal relevant range of production and sales alternatives.

\section{"What-If" Analysis versus changing the model}

For any given linear CVP analysis, we can ask a complete set of "what-if" questions about how increases and decreases in the sales price, unit variable costs, sales mix and fixed costs would affect the outcome. However, when we do that we are simply changing from one set of static assumptions to another set. This means that we are changing from one conventional linear problem to a somewhat different conventional linear problem. If the first two assumptions are relaxed to allow the sales price and unit variable costs to change continuously in response to the forces of supply and demand, we are not asking a "what if" question, we are changing the analysis from the practical linear approach to the theoretical nonlinear approach.

The invention formula derived for determination of percentage of profit on sales with amount of profit (Table 1).

\section{The core for the research gap}

\section{Increasing Capital Turnover (CTR)}

a) Increase sales with the same the investment base.

b) Decrease the investment base with the same sales level.

2. Increasing Profit Margin or Return on Sales (ROS)

a) Increase prices with no unfavourable effects on sales.

b) Decrease cost with no unfavourable effects on quality or increase in assets.

c) Increase sales with no changes in prices or costs.

\section{A simplified effective formula for ROS}

The recent invented simple and direct formula with the existing concepts is $\%$ of $\mathrm{P}$ on sales=P/V Ratio (1-BEP Ratio) or P/V Ratio- $(\mathrm{P} / \mathrm{V}$ Ratio*BEP Ratio) or $\mathrm{p} / \mathrm{v}$ ratio ${ }^{*}$ sms ratio.

\section{Drawn theme for current research from the literature}

What it felt with the "What-If" Analysis versus Changing the Model stated above in the literature it is clear that the analysis has a wide gap in between the existing linear analysis and the needed model for practical analytical system for nonlinear theory that ensure compatibility with the economic tendencies i.e. resembling the actual situations in analysis. The nonlinear model needs relaxation from the effects of assumptions for nonlinear analysis i.e. needs flexibility in value consideration of the variables to represent actual situations of varying values. It further felt that a common measurement in place of the present physical values is vital implication.

The hypothesis is that the amount of profit criteria of analysis impaired the flexibility and the proportional factor will perfectly substitute the amount for flexibility, commonness and a similar simplified model for the nonlinear analysis too. Further it is believed that it is the instrumental analysis helpful in the vital disclosure of the equilibrium level of price and output determination under the financial analysis in accordance with the economic analysis enabling the analysis extending from a tool of mare planning to a perfect model for management and control, as the rightful conclusion, ensuring much needed totality for the initiation works available in the literature stated.

\section{Hypothesis}

1. According to the subject economic and economic analysis, the economic trends and tendencies are natural and applicable for all the areas that come under the scope of economics and economic environments. The business unit is an economic entity and the principle of equilibrium price and output of economic theory is one of the important areas of applicable for business decisions. The true application of the principle in business needs derivation in terms of financial analysis, a perfect analytical system is not yet developed.

2. Being having a wide spread literature in economic analysis on the tendencies of initial rise and continued fall in price and initial fall and continuous rise in costs in the progress of business due to the impact of economies and diseconomies, market saturation, production 
Citation: Chandra RS, Banana K (2017) Operating and Financial Equilibrium: A Perfect Solution for Price Output Determination Irrespective of Competition. J Bus Fin Aff 6: 284. doi: 10.4172/2167-0234.1000284

Page 4 of 12

\begin{tabular}{|c|c|}
\hline \multicolumn{2}{|c|}{ Equations for Return on Sales (ROS) (adopted from the citation given below) } \\
\hline Using Units (X) & Using Sales Dollars (S) \\
\hline \multicolumn{2}{|c|}{ The Return on Sales Ratio before taxes is: } \\
\hline $\mathrm{ROS}=\mathrm{NIBT} \div \mathrm{PX}$ & $\mathrm{ROS}=\mathrm{NIBT} \div \mathrm{S}$ \\
\hline$R O S=[(P-V) X-T F C] \div P X$ & $R O S=[S-(V \div P)(S)-T F C] \div S$ \\
\hline When $X>0$ & When $\mathrm{S}>0$ \\
\hline$R O S=[(P-V) \div P]-(T F C \div P X)$ & $R O S=(1-V \div P)-(T F C \div S)$ \\
\hline $\mathrm{ROS}=\mathrm{CMR}-[(\mathrm{TFC} \div \mathrm{P}) \div \mathrm{X}]$ & ROS $=$ CMR $-($ TFC $\div S)$ \\
\hline For Cal Company: & For Cal Company: \\
\hline$P=10, V=6, T F C=\$ 120,000$ & $\mathrm{CMR}=1-6 \div 10=.4, \mathrm{TFC}=\$ 120,000$ \\
\hline $\mathrm{ROS}=[(10-6) \div 10]-(120,000 \div 10) \div \mathrm{X})$ & $\mathrm{ROS}=(1-.6)-(120,000 \div \mathrm{S})$ \\
\hline $\mathrm{ROS}=.4-(12,000 \div \mathrm{X})$ & $\mathrm{ROS}=.4-(120,000 \div \mathrm{S})$ \\
\hline $\begin{array}{c}\text { For example, what is the return on sales before taxes when } 60,000 \text { units are produced and } \\
\text { sold? }\end{array}$ & $\begin{array}{l}\text { For example, what is the return on sales before taxes when } \\
\qquad \text { sales }=\$ 600,000 ?\end{array}$ \\
\hline ROS before taxes $=.4-(12,000 \div 60,000)=.4-.2=.2$ or $20 \%$ & ROS before taxes $=.4-(120,000 \div 600,000)=.4-.2=.2$ or $20 \%$. \\
\hline \multicolumn{2}{|c|}{ The Return on Sales Ratio after taxes is: } \\
\hline $\mathrm{ROS}=\mathrm{NIAT} \div \mathrm{PX}$ & ROS $=$ NIAT $\div S$ \\
\hline$R O S=[(1-T)(P-V)(X)-(1-T)(T F C)] \div P X$ & $R O S=[(1-T)(S-(V \div P)(S)-T F C)] \div S$ \\
\hline When $X>0$ & When $S>0$ \\
\hline$R O S=[(1-T)(P-V) \div P]-[(1-T)(T F C) \div P X]$ & $R O S=(1-T)(1-V \div P)-(1-T)(T F C) \div S$ \\
\hline$R O S=(1-T)(C M R)-[(1-T)(T F C \div P) \div X]$ & $R O S=(1-T)(C M R)-(1-T)(T F C \div S)$ \\
\hline For Cal Company: & For Cal Company: \\
\hline $\mathrm{ROS}=[(1-.4)(10-6) \div 10]-[(1-.4)(120,000 \div 10) \div \mathrm{X}]$ & $\mathrm{ROS}=[(1-.4)(1-6) \div 10]-(1-.4).(120,000 \div \mathrm{S})$ \\
\hline $\mathrm{ROS}=.24-(7,200 \div \mathrm{X})$ & $\mathrm{ROS}=.24-(72,000 \div \mathrm{S})$ \\
\hline For example, what is the return on sales after taxes when 60,000 units are produced and sold? & For example, what is the return on sales after taxes when Sales $=\$ 600,000 ?$ \\
\hline ROS after taxes $=.24-(7,200 \div 60,000)=.24-.12=.12$ or $12 \%$ & ROS after taxes $=.24-(72,000 \div 600,000)=.24-.12=.12$ or $12 \%$ \\
\hline
\end{tabular}

Table 1: Showing the formula for determination $\%$ of profit on sales in the existing literature.

indivisibilities etc of production operations within the plan period of an individual or a firm is a natural phenomenon applicable for business decisions explained in managerial economics. The subject managerial economics and its projected analysis for business decisions is a clear indication that the business units are in rigorous analysis to arrive at a perfect solution for decision making on price and output. Though there are several theoretical explanations, there is no perfect practical analytical system for the purpose.

3. Unlike the economic analysis, the business units consider the financial/investment costs are distinct from operational costs. The development of a mathematical/methodical tool or model for derivation of the equilibrium price and output for a perfect business application needs interim of financial analysis with accounting costs instead of economic costs.

4. Till date, in the subject, there is no such method/tool/technique for the purpose other than the breakeven analysis. It is suffering from the imperative assumptions which carry the analysis into the zone away from the practical situations. The limitation of BEA is that not restricting the scope of applicability of assumptions to the realistic practical levels of economic situations and lack of flexibility to adopt for varying economic situations in continuation.

\section{Innovative formulae for analysis}

The innovative formulations and their effects are explained with the following hypothetical example.

The Company has an investment outlay of Rs.1600000/-(composed of 6\% debentures Rs.200000, 10\% banks loan Rs.600000/- apart from owners' funds). The variable cost per unit is Rs.20/- and total fixed costs comes to Rs.48000/-. The plant capacity is 20000 units. The company wants to get net profit after taxes to the tune of $15 \%$, at $40 \%$ capacity utilization. It is required to find out the selling price that yields the expected results in the current year.

\section{Solution:}

\section{Investment: Rs.1600000/-}

Debt to investment: 1:2 (800000:1600000) or $50 \%$ or .5

Weighted average cost of debt: $9 \%$ i.e., $\left(.25^{\star} 6+.75^{\star} 10\right)$ i.e., proportion of debt composition (2:6 or .25: .75)

Expected rate of profit on equity (ROE): $15 \%$

Tax rate: $40 \%$

Variable cost: Rs.20/- pu

Total fixed cost: Rs.48000/-

Determination of selling price per unit to attain the required rate profit on investment/on equity.

Under conventional mode: Any change in variables needs repetition of the process and has no direct integration and simplified formulation for calculations and presentation or for adapting to the changing conditions and changes in the prices, costs, volume and in required profits (Table 2) [6].

The following innovative formulation ensures the optimization of profits and profitability under predicted changes in all variables under varying environmental conditions apart from determination of price and deciding on price changes.

1. Determination of selling price per unit to attain the required rate profit with Simplified advanced formula enables to determine the selling price at a desired rate of profit on equity under financial planning is:

Formula 1: $\mathrm{C}=\left(\left(\mathrm{ROI}^{\star} \mathrm{I}\right)+\mathrm{F}\right) / \mathrm{Q}$ and $\mathrm{Sp}=\mathrm{V}+\mathrm{C}$

Formula 2: C/S*(1-BEP RATIO) OR PV RATIO*(1-BEP RATIO) OR SMS RATIO ${ }^{*}$ PV RATIO 
Citation: Chandra RS, Banana K (2017) Operating and Financial Equilibrium: A Perfect Solution for Price Output Determination Irrespective of Competition. J Bus Fin Aff 6: 284. doi: 10.4172/2167-0234.1000284

Page 5 of 12

\begin{tabular}{|c|c|c|}
\hline & & Rs. \\
\hline Required PAIT & $800000 * 15 \%$ & 120000 \\
\hline Required PAIBT & PAIT*1/(1-tax rate) i.e. $(120000 / 1-.4)$ & 200000 \\
\hline Add INTEREST & $(.06 * 200000+.1 * 600000)=(12000+60000)$ & 72000 \\
\hline Required PBIT & $(\mathrm{PBT}+\mathrm{I})$ & 272000 \\
\hline \multirow[t]{6}{*}{ Therefore, return on investment } & $(272000 / 1600000 * 100)$ & 17 \\
\hline & Required operating profit PBIT: & 272000 \\
\hline & Total fixed cost: & 48000 \\
\hline & TVC at $40 \%$ capacity $(40 \% * 20000)=8000$ units ${ }^{*} 20:$ & 160000 \\
\hline & Total sales: & 480000 \\
\hline & Selling price & 60 \\
\hline
\end{tabular}

Table 2: Conventional calculations of price determination.

\section{Invented application formula:}

Return on sales $(\mathrm{ROS})=\mathrm{ROI} / \mathrm{ITR}$

ITR=sales/investment OR S/I

Where Sales value $(S)=$ price $(\mathrm{sp}) \times(\mathrm{Q})$ units sold

$\mathrm{S}=\mathrm{Q}$ X SP AND $\mathrm{SP}=(\mathrm{V}+\mathrm{C})$

$\mathrm{ITR}=\mathrm{Q}(\mathrm{V}+\mathrm{C}) / \mathrm{I}$ AND

ROS=ROI/ITR or ROI/ Q $(\mathrm{V}+\mathrm{C}) / \mathrm{I}$ or $\mathrm{ROI}^{\star} \mathrm{I} / \mathrm{Q}(\mathrm{V}+\mathrm{C})$

OTHER WAY ROS $=\mathrm{S}-(\mathrm{QV}+\mathrm{F}) / \mathrm{S}$ and $\mathrm{S}=\mathrm{Q}(\mathrm{V}+\mathrm{C})$ or $(\mathrm{QV}+\mathrm{QC})$

$\mathrm{ROS}=(\mathrm{QV}+\mathrm{QC})-(\mathrm{QV}+\mathrm{F}) /(\mathrm{QV}+\mathrm{QC})$

$\mathrm{ROS}=(\mathrm{QC}-\mathrm{F}) / \mathrm{Q}(\mathrm{V}+\mathrm{C})$

Therefore,

$\mathrm{ROI}^{\star} \mathrm{I} / \mathrm{Q}(\mathrm{V}+\mathrm{C})=(\mathrm{QC}-\mathrm{F}) / \mathrm{Q}(\mathrm{V}+\mathrm{C})$

$\mathrm{ROI}^{*} \mathrm{I}=\mathrm{QC}-\mathrm{F}=\left(\mathrm{ROI}^{\star} \mathrm{I}\right)+\mathrm{F}=\mathrm{QC}$

Verification of the formula: Required rate of profit on equity (ROE): $15 \%$

As the tax rate is $40 \%$ the required ROIAIBT: $\mathrm{ROE}^{\star}(1-\mathrm{DIR}) /(1-$ $\mathrm{TR})=.15^{\star} 1 / 2 /(1-.4)=.075 / .6=.125$

Required ROIBIT OR ROI: ROIAIBT+(WACOD x DIR $)=.125+$ $(.09 \times 1 / 2)=.125+.045=.17$ or $17 \%$

\section{$\mathrm{ROS}=\mathrm{ROI} / \mathrm{ITR}$}

Therefore: $\mathrm{C}=\left(\left(.17^{\star} 1600000\right)+48000\right) / 8000$

$$
\begin{aligned}
& \mathrm{C}=(272000+48000) / 8000=320000 / 8000 \\
& \mathrm{C}=\text { Rs. } 40 /- \text { and given } \mathrm{V}=\mathrm{Rs} .20 \\
& \mathrm{SP}=20+40=\text { Rs. } 60 /-
\end{aligned}
$$

Sales $=60 * 8000=$ Rs. $480000 /-$ ITR $=480000 / 1600000=0.3$

$\mathrm{ROS}=\mathrm{ROI} / \mathrm{ITR}=.17 / .3=0.5667$ or $56.67 \%$.

1. In collaboration with the following derivation for arriving the innovative formula cited in the literature, enable the Breakeven analysis to extend application for ensuring a perfect solution in determination of operating and financial equilibrium price and output with aptly flexible implications and able to provide the analysis adapting to the changing environmental conditions.

Other way ROS $=\mathrm{PV}$ ratio $^{*}(1-\mathrm{BEP}$ ratio)

Where,

\section{$\mathrm{S}=\mathrm{V}+\mathrm{C}$ AND $\mathrm{C}=\mathrm{F}+\mathrm{P}$ \\ PV RATIO $=\mathrm{C} / \mathrm{S}$ \\ $\mathrm{BEP}=\mathrm{F} / \mathrm{PV}$ RATIO}

BEP TO TOTAL SALES RATIO $($ BEPR $)=B E P / S$

$\mathrm{SMS}=\mathrm{P} / \mathrm{PV}$ RATIO $=\mathrm{P} /(\mathrm{C} / \mathrm{S})$

THEN:

$\mathrm{BEPR}=(\mathrm{F} / \mathrm{pv}$ Ratio $) / \mathrm{S}$ OR $\mathrm{F} / \mathrm{c} / \mathrm{s} / \mathrm{S}=\mathrm{F} / \mathrm{C}$ or BEP Ratio $(\mathrm{BEPR})=\mathrm{F} / \mathrm{C}$ SMS RATIO $=\mathrm{P} / \mathrm{c} / \mathrm{s} / \mathrm{S}=\mathrm{P} / \mathrm{C}$ or SMS ratio $(\mathrm{SMSR})=\mathrm{P} / \mathrm{S}$

AS $\mathrm{C}=\mathrm{F}+\mathrm{P}$

Sum of ratios (BEPR + SMSR):

$\mathrm{F} / \mathrm{C}+\mathrm{P} / \mathrm{C}=(\mathrm{F}+\mathrm{P}) / \mathrm{C}=\mathrm{C} / \mathrm{C}=1$

$\mathrm{P} / \mathrm{C}=1-\mathrm{F} / \mathrm{C}$

WHERE PROFIT $=S M S^{*}$ PV RATIO

Operating profit ratio or PRFIT RATIO=SMS RATIO ${ }^{*} \mathrm{P} / \mathrm{V}$ $\mathrm{RATIO}=\mathrm{P} / \mathrm{C}^{\star} \mathrm{C} / \mathrm{S}=\mathrm{P} / \mathrm{S}$

other wise

$\mathrm{S}=\mathrm{BEP}+\mathrm{SMS}$ and hence

SMS RATIO AND BEP RATIO (bep/s + sms/s)=1

PROFIT RATIO or RATE OF PROFIT ON SALES $(\mathrm{ROS})=(1-\mathrm{F} /$ C) ${ }^{\star} \mathrm{C} / \mathrm{S}$

OR C/S*(1- BEP RATIO) OR PV RATIO ${ }^{\star}(1-$ BEP RATIO) OR SMS RATIO*PV RATIO

Verification with the example: $\mathrm{Pv}$ ratio $=40 / 60=66.67 \%$

Bep $=48000 / 40=1200$ units; Bep ratio $=1200 / 8000=.15$ or $15 \%$

ROS $=.6667(1-.15)=.6667^{\star} .85=.5667$ or $56.67 \%$.

Required rate of return on investment to get $15 \%$ on equity $=.5667^{\star} .3=.17$ or $17 \%$ and the required rate of return on sales to get the desired rate of profit on equity is $56.67 \%$ at a volume of 8000 units with selling price of Rs. 60 and variable cost of Rs. 20 p.u. and a total fixed cost of Rs.48000/-.

With the example problem the attainment $15 \%$ return on equity or $17 \%$ return on investment, the required rate of return on sales will be $56.67 \%$ at the investment turnover rate of 0.3 with revenue of Rs.480000/- the required ROS become lesser at a higher amount of turnover and vice versa. Similarly, a reduced selling price leads to reduction of ROS and needs enhancement of the amount of turnover 
and vice versa. This formulation established a direct mathematical relation among them for a perfect dynamic programmed planning and control system for attaining the best possible level or optimum rate of profit on sales and on equity at different levels of activity in progress of the operations under the dynamic conditions/ considerations.

\section{$\mathrm{C}=\left(\left(\mathrm{ROI}^{\star} \mathrm{I}\right)+\mathrm{F}\right) / \mathrm{Q}$ and $\mathrm{Sp}=\mathrm{V}+\mathrm{C}$}

The above is an investment implication of profit planning through integrated formulation of the operational planning and analysis with the financial planning and analysis, a modified formula, though looks similar with the conventional BEA for profit planning i.e., a fixed amount of profit under different levels of activity, it provides a different and more competent effect with the rate of profit in place of a constant amount of profit. The $\mathrm{C}$ and $\mathrm{Q}$ are inversely proportional when profit $(\mathrm{P})$ is constant in total. As the required rate of return on investment is said to be fixed and the total amount of profit would be constant until the amount of investment or cost of investment i.e., rate of profit expected or the structure of capital varies. It is natural that the investments would likely get changed when level of activity changes and the rate of profit vary according to the interest rate trends of the economy and also with respect to the changes in capital structure. Therefore, consideration of a dynamic value for the variable i.e., profits is prerequisite for ensuring closer to the reality and hence the accuracy. The rate of profit ensures the dynamic state of profits and it has a greater and wider implication than the stipulated amount of profit in planning.

\section{$\mathrm{ROS}=\mathrm{p} / \mathrm{v}$ ratio ${ }^{\star}(1-\mathrm{BEP}$ ratio $)$}

The above formula enables the measurement of effects of time to time changes in environment and in investment on the rate of profit expected from the operations through dynamic planning process all along the progress of operations of the business. This helps for managing and controlling the results of operations through deciding the required changes in price, costs and volume that able to ensure the attainment of desired rate of profit on investment or determining the optimum rate of profit i.e., ROS, ROI \& ROE directly in accordance with time to time effects of changing environments during the progress of the business operations of the specified period. Hence this simplifies the process of determination of the selling price at different levels of activity for the same rate of return on sales, investment, equity etc.

The concept of determination of ROS, ROI and ROE through the application of Breakeven Point with the following innovative formulae along with the above enable to arrive the planning for profits with the changing values of all variables i.e. price, costs, volume and even investments under dynamic conditions of internal and external environmental changes at different stages in progress of operations of the business organization.

Formulae: 3 (Tables 3 and 4).

\section{The innovative analysis and applications}

The way how it enables the integration can be explained with the following hypothetical example. A company asserted the following initial situation and the effects while sales progresses during the year 2016-17. It is requested to determine the most profitable level of price and output at which the firm secures maximum returns.

The Company has an investment outlay of Rs.3000000/- (composed of $4 \%$ debentures Rs.750000, 6\% banks loan Rs.750000/- apart from owners' funds). The variable cost per unit is Rs.60/- and selling price is Rs.100/- per unit, total fixed costs come to Rs.80000/-. The plant capacity is 22000 units. The company's predictions on changes in costs, price, and investments during the progress of operations to the full capacity utilization are as given below. The company wishes to know the optimum rate of profit on sales and on equity under the progressive implication of operations [7]. How do you optimize aggregate rate of profit and amount of profits are maximized under the said conditions? Also determine the average and marginal price and level of output and sales at which the firm stays at equilibrium.

The company predicted the following changes during the progress at different levels of activity in the year 2016-17 (Table 5).

Note: even if there is any change in between the limits stated, it can

\begin{tabular}{|c|c|c|c|}
\hline $\begin{array}{l}\text { Concept of profit (form operating profit } \\
\text { to profit on equity) }\end{array}$ & $\begin{array}{l}\text { Amount of profit through physical values (needs all } \\
\text { physical values) }\end{array}$ & $\begin{array}{l}\text { Amount of profit through } \\
\text { proportions (needs at } \\
\text { least one values and one } \\
\text { proportion) }\end{array}$ & $\begin{array}{l}\text { Proportion rate through proportions no } \\
\text { need of physical value (innovation) }\end{array}$ \\
\hline Return on sales & Operating profit/sales & $S^{*} R$ on $S$ & ROS $=p / v$ Ratio*(1-BEPR) \\
\hline $\begin{array}{c}\text { Operating profit on sales to investment } \\
\text { PBIT to INV }\end{array}$ & (Sales -operating exp.)/investment & $\left(\mathrm{S}^{*} \mathrm{P}\right.$ on $\left.\mathrm{S}\right) /$ investment & ROI=ROS*ITR (existed \& in use) \\
\hline $\begin{array}{l}\text { Profit after interest but before } \\
\text { taxes(PAIBIT) }\end{array}$ & PBIT-INT & $\mathrm{PAIBT}^{*}(1-\mathrm{IR})$ & $\begin{array}{c}\text { Innovation: ROIAIBT }=\text { ROI or ROIBIT - } \\
\text { (INTR*DTIR) }\end{array}$ \\
\hline $\begin{array}{c}\text { Profit after interest and taxes (PAIT) } \\
\text { on investment }\end{array}$ & PAIBT-TAX & $\mathrm{PAIBT}^{*}(1-\mathrm{TR})$ & Innovation: ROIAIT=ROIAIBT*((1-TR) \\
\hline $\begin{array}{c}\text { Profit after interest and taxes (PAIT) } \\
\text { on equity }\end{array}$ & PAIBT-TAX & $\mathrm{PAIBT}^{*}(1-\mathrm{TR})$ & Innovation: ROE= ROIAIT /(1-DIR) \\
\hline
\end{tabular}

Table 3: Comparison of conventional and the innovative formulae for calculations of ROS to ROE.

\begin{tabular}{|c|c|c|c|}
\hline $\begin{array}{c}\text { Concept of profit } \\
\text { (form operating profit to profit on equity) }\end{array}$ & $\begin{array}{l}\text { Amount of profit through physical } \\
\text { values } \\
\text { (needs all physical values) }\end{array}$ & $\begin{array}{l}\text { Amount of profit through proportions } \\
\text { (needs one values) }\end{array}$ & $\begin{array}{l}\text { Proportion rate through proportions no } \\
\text { need of physical value (innovation) }\end{array}$ \\
\hline Profit after interest and taxes for investment & PAIT+TAX & $\mathrm{PAIT}^{*}(1+\mathrm{TR})$ & ROIAIT=ROE *((1-DIR) (innovation) \\
\hline Profit after interest but before taxes(PAIBT) & PAIT+TAX & $\mathrm{PAIT}^{*}(1+\mathrm{TR})$ & ROIAIBT=ROIAIT/(1-TR) \\
\hline $\begin{array}{c}\text { Profit before interest \&taxes(PBIT) on } \\
\text { investment or operating profit on investment }\end{array}$ & PAIBT+INT & PAIBT $^{*}(1+$ WAIR $)$ & $\begin{array}{c}\mathrm{ROI} \text { or ROIBIT }=\text { ROIAIBT+(INTR*DTIR) } \\
\text { (innovation) }\end{array}$ \\
\hline $\begin{array}{c}\text { Operating profit on sales to investment PBIT } \\
\text { to INV }\end{array}$ & (Sales -operating exp.)/investment & ( $\mathrm{S}^{*} \mathrm{P}$ on $\left.\mathrm{S}\right) /$ investment & $\begin{array}{c}\text { ROI=ROS*ITR } \\
\text { (existed and in use) }\end{array}$ \\
\hline Return on sales & Operating profit/sales & $\mathrm{S}^{*} \mathrm{R}$ on $\mathrm{S}$ & ROS=p/v Ratio*(1-BEPR) \\
\hline
\end{tabular}

Table 4: Comparison of conventional and the innovative formulae for calculations of ROE to ROS. 
Citation: Chandra RS, Banana K (2017) Operating and Financial Equilibrium: A Perfect Solution for Price Output Determination Irrespective of Competition. J Bus Fin Aff 6: 284. doi: 10.4172/2167-0234.1000284

Page 7 of 12

be implicated at its stage of change in the progress of operations and it does not have any impact on the principle of equilibrium.

\section{Solution}

- It is required to find out the selling price that yields the expected results in the current year and what is the optimum level of price, output and sales at which the firm attains optimum operational and the financial equilibrium price and the output under the above conditions. The following calculations enable to determine financial/ operating equilibrium (Tables 6-10) (Figure 3).
- With the help of the above table and graph in comparison with the conventional BEA, it is possible to understand that either rise in cost or fall in price or both leads to increase in breakeven point is the observation of conventional BEA, a negative impact indication. The increase in cost and a fall in price are the instruments for a positive change in volume hence the implication of breakeven should be inconsideration with the effect on volume apart from the changes in price and costs i.e. the BEP Ratio instead of BEP for understanding the net impact on the performance of the product/firm is more important than knowing the just trend in the position of breakeven point [8].

\begin{tabular}{|c|c|c|c|c|c|c|c|}
\hline Units in '000 & $0-2$ & $0-5$ & $5-8$ & $8-12$ & $12-15$ & $15-20$ & $20-22$ \\
\hline Selling price & 100 & 100 & 95 & 92 & 85 & 80 & 78 \\
\hline Variable cost & 60 & 60 & 58 & 56 & 60 & 75 & 76 \\
\hline Fixed costs & 80000 & 80000 & 80000 & 88000 & 90000 & 90000 & 90000 \\
\hline Total investment & 3000000 & 3000000 & 3000000 & 3000000 & 3000000 & 3200000 & 3300000 \\
\hline Debt to total inv. & $50 \%$ & $50 \%$ & $50 \%$ & $50 \%$ & $50 \%$ & $50 \%$ & $50 \%$ \\
\hline WACOD & $5 \%$ & $5 \%$ & $5 \%$ & $5 \%$ & $5 \%$ & $5 \%$ & $5 \%$ \\
\hline Extent of units & 2000 & 3000 & 3000 & 4000 & 3000 & 5000 & 2000 \\
\hline
\end{tabular}

Table 5: Changes predicted during the progress of operations.

\begin{tabular}{|c|c|c|c|c|c|c|c|c|}
\hline Description & Formula & \multicolumn{7}{|c|}{ Values at progressive level of activity (production and sales) } \\
\hline Marginal units of sales & As given & 2000 & 3000 & 3000 & 4000 & 3000 & 5000 & 2000 \\
\hline Marginal selling price & As given & 100 & 100 & 95 & 92 & 85 & 80 & 78 \\
\hline Total sales revenue & (units $\times \mathrm{sp}$ ) & 200000 & 300000 & 285000 & 368000 & 255000 & 400000 & 156000 \\
\hline Cumulative units & Previous level+lstest & 2000 & 5000 & 8000 & 12000 & 15000 & 20000 & 22000 \\
\hline Cumulative total sales & Previous level+lstest & 200000 & 500000 & 785000 & 1153000 & 1408000 & 1808000 & 1964000 \\
\hline Marginal variable cost per unit & As given & 60 & 60 & 58 & 56 & 60 & 75 & 76 \\
\hline Total variable cost & & 120000 & 180000 & 174000 & 224000 & 180000 & 375000 & 152000 \\
\hline Cumulative total Vc & Previous level+Istest & 120000 & 300000 & 474000 & 698000 & 878000 & 1253000 & 1405000 \\
\hline Weighted average SP & Cum.sales/cum.units & 100.0 & 100.0 & 98.13 & 96.08 & 93.87 & 90.40 & 89.27 \\
\hline Weighted average Vc & Cum. Vc/cum.units & 60.0 & 60.0 & 59.3 & 58.2 & 58.5 & 62.7 & 63.9 \\
\hline
\end{tabular}

Table 6: Calculation of required values of weighted average selling price and weighted average variable costs and cumulative total sales and cumulative variable costs.

\begin{tabular}{|c|c|c|c|c|c|c|c|c|}
\hline \multirow{2}{*}{$\begin{array}{c}\text { Particulars } \\
\text { Progressive activity units }\end{array}$} & \multirow{2}{*}{$\begin{array}{c}\text { Formula } \\
\text { As calculated above }\end{array}$} & \multicolumn{7}{|c|}{ Values under progressive level of activity } \\
\hline & & 2000 & 5000 & 8000 & 12000 & 15000 & 20000 & 22000 \\
\hline (wa.sp)Weighted average SP & As calculated above & 100 & 100 & 98.13 & 96.08 & 93.87 & 90.4 & 89.27 \\
\hline (wa.vc) Weighted average VC & As calculated above & 60 & 60 & 59.25 & 58.17 & 58.53 & 62.65 & 63.86 \\
\hline TFC & As given & 80000 & 80000 & 80000 & 88000 & 90000 & 90000 & 90000 \\
\hline C & wa.sp -wa.vc & 40 & 40 & 38.88 & 37.92 & 35.33 & 27.75 & 25.41 \\
\hline Contribution ratio & C/WASP & 0.40 & 0.40 & 0.40 & 0.39 & 0.38 & 0.31 & 0.28 \\
\hline BEP units & $\mathrm{FC} / \mathrm{C}$ & 2000 & 2000 & 2058 & 2321 & 2547 & 3243 & 3542 \\
\hline (BEPR)BEP ratio & BEP/CUMS & 1.00 & 0.40 & 0.26 & 0.19 & 0.17 & 0.16 & 0.16 \\
\hline ROS or Avg.p.\% & pv ratio*(1-BEPR) & 0 & 0.240 & 0.294 & 0.318 & 0.312 & 0.257 & 0.239 \\
\hline
\end{tabular}

Table 7: Determination of average return on sales or return on sales (AROS/ ROS).

\begin{tabular}{|c|c|c|c|c|c|c|c|c|}
\hline \multirow{2}{*}{$\begin{array}{l}\text { Units of output and sales } \\
\text { (in 000') }\end{array}$} & \multirow[t]{2}{*}{ Formula } & \multicolumn{7}{|c|}{ Progressive output and sales } \\
\hline & & 2 & 5 & 8 & 12 & 15 & 20 & 22 \\
\hline Average rate of ROFIT on sales (ROS) & As calculated above & 0.000 & 0.240 & 0.294 & 0.318 & 0.312 & 0.257 & 0.239 \\
\hline (inv)Amount of investment (in 000') & As given & 3000 & 3000 & 3000 & 3000 & 3000 & 3200 & 3300 \\
\hline Cumulative Sales Revenue (in 000') & As calculated above & 200 & 500 & 785 & 1153 & 1408 & 1808 & 1964 \\
\hline Inv. Turnover ratio (INVTR) & CUMS/INV. & 0.07 & 0.17 & 0.26 & 0.38 & 0.47 & 0.57 & 0.60 \\
\hline ROI/ROIBIT & ROS*INVTR & 0.00 & 0.04 & 0.08 & 0.12 & 0.15 & 0.15 & 0.14 \\
\hline Debt to inv (DIR) & DEBT/INV & 0.5 & 0.5 & 0.5 & 0.5 & 0.5 & 0.5 & 0.5 \\
\hline Weighted average cost of debt & as given & 0.05 & 0.05 & 0.05 & 0.05 & 0.05 & 0.05 & 0.05 \\
\hline ROIAIBT & ROI-(WACOD*DIR) & -0.0250 & 0.0150 & 0.0520 & 0.0974 & 0.1216 & 0.1203 & 0.1171 \\
\hline $\operatorname{Tax} 40 \%(\mathrm{~T})$ & AS GIVEN & 0 & 0.4 & 0.4 & 0.4 & 0.4 & 0.4 & 0.4 \\
\hline ROIAIT/ROE (100\%EQ) & $\mathrm{ROIBIT}^{*}(1-\mathrm{T})$ & -0.025 & 0.024 & 0.0462 & 0.07344 & 0.08796 & 0.08718 & 0.08526 \\
\hline ROEAIT/ROE (50\% DT) & ROIAIBT $^{*}(1-\mathrm{T}) /(1-\mathrm{DIR})$ & -0.05 & 0.018 & 0.0624 & 0.11688 & 0.14592 & 0.14436 & 0.14052 \\
\hline
\end{tabular}

Table 8: Determination of ROI and ROE. 
Citation: Chandra RS, Banana K (2017) Operating and Financial Equilibrium: A Perfect Solution for Price Output Determination Irrespective of Competition. J Bus Fin Aff 6: 284. doi: 10.4172/2167-0234.1000284

Page 8 of 12

\begin{tabular}{|c|c|c|c|c|c|c|c|c|c|}
\hline \multirow{2}{*}{$\begin{array}{c}\text { Particulars } \\
\text { Marginal units of sale (MS) }\end{array}$} & \multirow{2}{*}{$\begin{array}{l}\text { Formula } \\
\text { As given }\end{array}$} & \multicolumn{8}{|c|}{ Values under progressive additional level of activity } \\
\hline & & 0 & 2000 & 5000 & 3000 & 4000 & 3000 & 5000 & 2000 \\
\hline Marginal SP (MSP) & As given & 100 & 100 & 100 & 95 & 92 & 85 & 80 & 78 \\
\hline Marginal VC (MVC) & As given & 60 & 60 & 60 & 58 & 56 & 60 & 75 & 76 \\
\hline Marginal fixed cost (MFC) & As given & 80000 & 80000 & 0 & 0 & 8000 & 2000 & 0 & 0 \\
\hline Marginal contribution (MC) & MSP-MVC & 40 & 40 & 40 & 37 & 36 & 25 & 5 & 2 \\
\hline Mcon. Ratio (MCR) & MC/MSP & .4 & 0.4 & 0.4 & 0.39 & 0.39 & 0.29 & 0.06 & 0.03 \\
\hline Marginal BEP (MBEP) & $\mathrm{MFC} / \mathrm{MC}$ & - & 2000 & 0 & 0 & 222 & 80 & 0 & 0 \\
\hline Marginal BEP ratio (MBEPR) & MBEP/MS & - & 1 & 0 & 0 & 0.056 & 0.027 & 0 & 0 \\
\hline Marginal rate of profit (MROS) & $\mathrm{MCR}^{*}(1-\mathrm{MBEPR})$ & - & 0.000 & 0.400 & 0.389 & 0.370 & 0.286 & 0.063 & 0.026 \\
\hline $\begin{array}{l}\text { Marginal rate of profit on equity } \\
\text { MROE }\end{array}$ & $\begin{array}{l}\mathrm{MROS}^{*}(1-\mathrm{TR}) /(1- \\
\text { DIR })\end{array}$ & - & 0 & 0.48 & 0.4668 & 0.444 & 0.3432 & 0.0756 & 0.0312 \\
\hline
\end{tabular}

Table 9: Determination of marginal rate of return (MROS) on progressive extension of sales and marginal rate of return on equity (MORE).

\begin{tabular}{|c|c|c|c|c|c|c|c|c|}
\hline $\begin{array}{l}\text { Cum output \& } \\
\text { sales units }\end{array}$ & BEPR\% & ROS\% & MRROS\% & ROI\% & ROIAIBT\% & $100 \%$ equityR0E\% & $50 \%$ equity ROE\% & MROE\% \\
\hline 2000 & 1 & 0 & 0 & -2.5 & -2.5 & 0 & -5 & 0 \\
\hline 5000 & 40 & 24 & 40 & 4 & 1.5 & 2.4 & 1.8 & 48 \\
\hline 8000 & 25.72 & 29.43 & 38.95 & 7.7 & 5.2 & 4.62 & 6.24 & 46.68 \\
\hline 12000 & 19.34 & 31.83 & 36.96 & 12.24 & 9.74 & 7.344 & 11.688 & 44.4 \\
\hline 15000 & 16.98 & 31.25 & 28.63 & 14.66 & 12.16 & 8.796 & 14.592 & 34.32 \\
\hline 20000 & 16.22 & 25.72 & 6.25 & 14.53 & 12.03 & 8.718 & 14.436 & 7.56 \\
\hline 22000 & 16.1 & 23.88 & 2.56 & 14.21 & 11.71 & 8.526 & 14.052 & 3.12 \\
\hline
\end{tabular}

Table 10: Determination of equilibrium price and output and optimum rate of return on sales or Operating profit on sales.

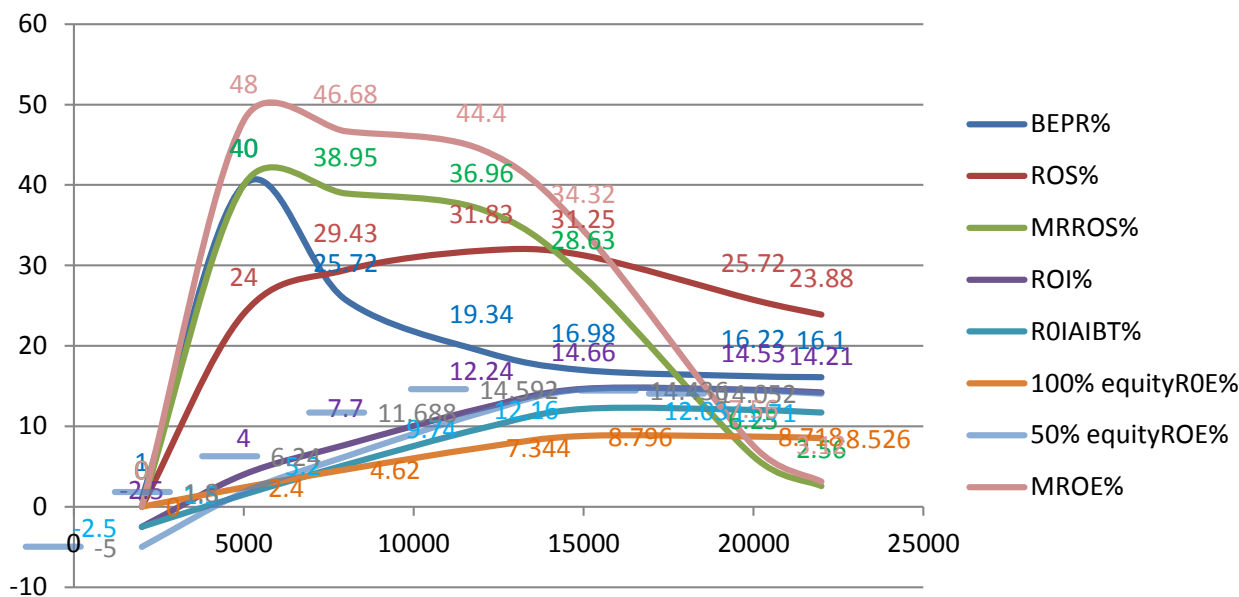

Figure 3: Graphical expression of the data of the Table 10 showing the points of equilibrium points with the curves of all possible variables

- It is made possible to understand through the trends in breakeven ratio curve of the above graph. A fall in BEP ratio with effect from changes in cost and prices increase/decrease, it is a positive sign and vice versa. Further how far it is beneficial is determined with the trends in average rate of return on sales/average rate of return on sales (ROS/AROS) and average rate of return on investment (ROI/AROI) and further return on equity/average rate of return on equity (AROE/ ROE) curves corresponding to the changed conditions.

- With the above graph studying the trends in BEP ratio curve together with the AROS helps to understand the net impact of the changes on profitability of the product/firm. Either the formula to calculate the AROS/ROS $\{\mathrm{PV}$ Ratio*(1-BEPR) $\}$ or the trends of the BEP ratio and AROS curves explain that the two are inversely proportional; they explain the net impact of the changes on the performance of the product. Therefore, the average rate of profit is one of the vital components to decide the right volume of output and sales. The intersection point of BEPR and the AROS/ROS clearly demarcates the operations in to two zones i.e., risk implied and risks free zones with higher degree of clarity and warning system under changing conditions. This can be supplemented or substituted with the BEP and SMS zones of conventional BEA [9].

- In simple optimal risk breakeven point is BEPR=AROS.

- The invention of determining the marginal rate of return on sales corresponding to the average rate of return and observation of their trends through the curves AROS and MROS enable to study the incremental impacts of volume together with change in other variables helps to understand the net effect i.e., state of the adversity or advantage when continue the enhancement of the volume of output and sales.

- The trends on AROS \& MROS enable to determine the optimum level of output and sales at which the profitability on operations of the product is optimized under changing conditions. It is 
Citation: Chandra RS, Banana K (2017) Operating and Financial Equilibrium: A Perfect Solution for Price Output Determination Irrespective of Competition. J Bus Fin Aff 6: 284. doi: 10.4172/2167-0234.1000284

Page 9 of 12

identifiable that the volume and prices corresponding to the point on the AROS curve where it got its maximum and from where it tends to fall and furthermore importantly at the same point where it is intersected by MROS curve. The point further explains the optimization of overall performance/operational efficiency of the product/firm. Therefore, the efficiency maximization point in simple is the AROS=MROS as a natural principle of equilibrium efficiency derived with the invention analysis.

- Operational efficiency equilibrium can be stated as AROS=MROS

- As the organization's objective of ensuring maximization of profits and profitability on the investments (ROI) is more important than the profitability on sales (ROS), therefore the effects of changes on returns have been analyzed on the investments apart from sales.

- With the possibility of directly determining the rate of return on investment (AROI/ROI) i.e., $\left\{\mathrm{pv} \operatorname{ratio}^{\star}(1-\mathrm{BEP} \text { Ratio })^{\star} \mathrm{ITR}\right\}$ corresponding to the changes and trends in the curve enable to explain the impacts of operational changes on total investment and determine the right level of activity for maximizing the effectiveness of performance of the product on total investments. It is possible to understand by observation of the trends in the ROI curve.

- The investments of a firm composed of a mixture of debt and equity and the need to understand the effectiveness of operations on equity, the average rate of return on equity(AROE) curve together with the marginal rate of return on equity (MORE) curve enable to determine the level of activity or operations at which the returns on equity are optimized under the conditions of changes not only on operational variables but also the changes if any there in the investments and in the capital structure and the cost of debt.
- The level of operations that maximizes the profitability on equity is determined at the prices and volume of sales at which the AROE curve is intersected by MROE curve. As the point of intersection is at the point where the AROE reaches to its maximum and from where it tends to fall and furthermore importantly at the same point where it is intersected by MORE curve. Therefore, the optimization point of effectiveness of operation is: AROE=MORE.

In simple the principle of equilibrium effectiveness point of operations is:

Under the leverage conditions AROE=MORE.

Under no leverage conditions ROIAIT=MORE.

- $\quad$ Further through the observation of trends in curves of ROI, ROIAIBT, ROIAIT ( $100 \%$ equity) and ROE ( $50 \%$ equity), enable to understand how the ROE would be affected with respect to changes in financial leverage and the cost of debt together with the changes in operating leverage under the changing environment. Hence it enables to determine the right structure of capital that optimizes the risk of investment/financial leverage in accordance with the optimization of operational leverage. Therefore, this is the only analysis able to integrate the three systems of analysis i.e., economic, financial and operational analysis commonly used in isolation for effective business decisions [10].

- $\quad$ For the purpose of legibility and clarity in understanding the equilibrium points were explained individually here under (Table 11 and Figure 4).

The above graph at the intersection pint between ROS AND MROS exhibits the equilibrium point or optimization point of efficiency of operations. The state of AROS curve exhibits to effect of changes in operating leverage under changing conditions on return on sales.

\begin{tabular}{|c|c|c|c|c|c|c|c|c|c|}
\hline $\begin{array}{c}\text { Progressive output and } \\
\text { sales }\end{array}$ & $\begin{array}{c}\text { Cum OP and } S \\
\text { units }\end{array}$ & Total fixed cost & MSP & MVC & Average SP & Average VC & BEPR & AROS/ROS & MROS \\
\hline $0-2000$ & 2000 & 80000 & 100 & 60 & 100 & 60 & 100 & 0 & 0 \\
\hline $2000-5000$ & 5000 & 80000 & 100 & 60 & 100 & 60 & 40 & 24 & 24 \\
\hline $5000-8000$ & 8000 & 80000 & 95 & 58 & 98.13 & 59.3 & 25.72 & 29.43 & 38.95 \\
\hline $8000-12000$ & 12000 & 88000 & 92 & 56 & 96.08 & 58.2 & 19.34 & 31.83 & 36.96 \\
\hline $12000-15000$ & 15000 & 90000 & 85 & 60 & 93.87 & 58.5 & 16.98 & 31.25 & 28.63 \\
\hline $15000-20000$ & 20000 & 90000 & 80 & 75 & 90.4 & 62.7 & 16.22 & 25.72 & 6.67 \\
\hline $20000-22000$ & 22000 & 90000 & 78 & 76 & 89.27 & 63.9 & 16.1 & 23.88 & 2.56 \\
\hline
\end{tabular}

Table 11: Table contained the data for Graphical expression of equilibrium output and sales and determination of optimum rate of profit on sales and point of optimization of operating profit ratio/ efficiency.

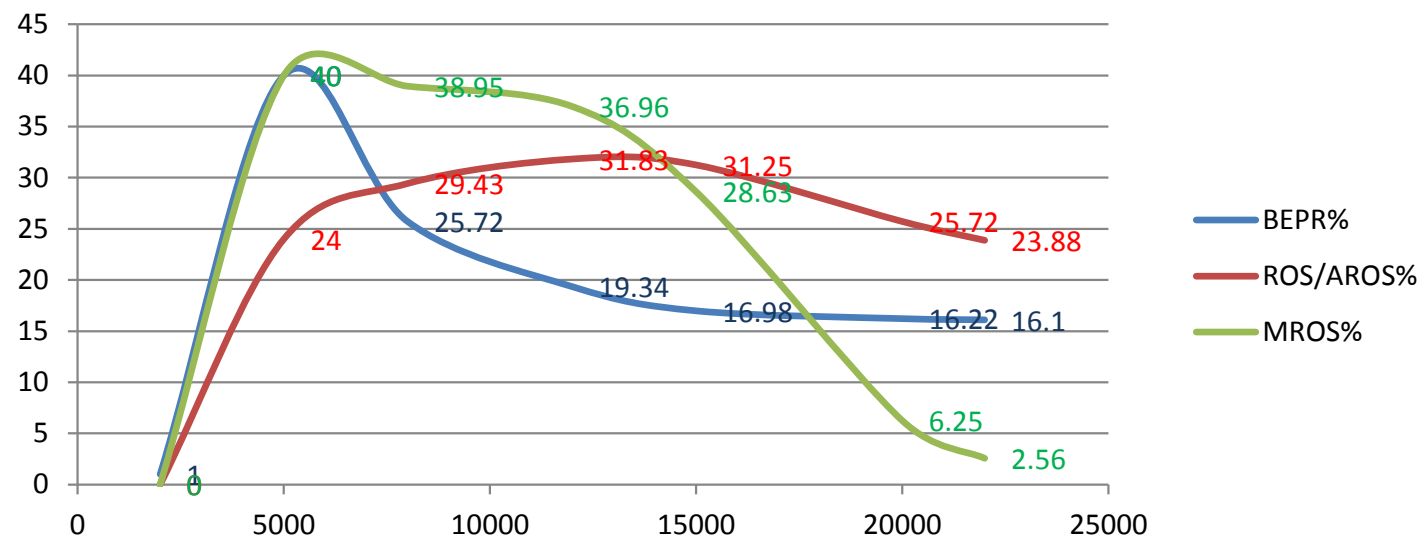

Figure 4: Graphical expression of the data of the Table 11 showing separately the optimum operating efficiency or operating equilibrium price and output. 
Further the BEPR and AROS directly related to PV ratio (contribution ratio), and the two are inversely proportional; it is observed that the tendency of the curves either in rise or in fall shows a similar proposition in opposite direction. As the two viz. the BEPR and the AROS are inversely proportional, the intersection between the AROS and BEPR is the indicator of risk zone i.e., the difference between the volume of sales at BEPR $100 \%$ (the BEP) and the point of intersecting the AROS by the BEPR and non-risk zones of operations i.e., the zone beyond the intersection of BEPR and AROS. It is a unique inference made possible to derive through this innovation, the basic theme adopted from the below citation. This gives more clarity by demarcating the zone of likely risks apart from the loss and profit zones, when compared to the BEP \& SMS demarcations used in conventional BEA (Table 12 and Figure 5).

The above table and graph helps to understand the state of impact of operating leverage together with financial leverage on return on equity. The above exhibit not only clears that the greater the financial leverage the lower the cost of investment and greater the return on equity by a crease in operating leverage beyond the intersection points and greater the risk of financial leverage when the operating leverage move below the intersection points. It not only confesses the common phenomena of financial analysis but also able to give a clear demarcation by determine the zone of operational leverage that implies high financial risk and the zone of low and no risk implication through the points of intersection between or among the curves and $\mathrm{X}$ axis detailed here under. The unique implication is that the exhibit explains the effects of leverages under the changing economic environmental conditions.

A high-risk zone is identified with the operation levels equal to the point of (leverage equity) $50 \%$ equity ROE curve intersecting the $\mathrm{X}$ axis and a relative high-risk zone between intersection of $\mathrm{X}$ axis and the ROIAIT (ROE $100 \%$ equity) curve by (the leverage equity) 50\% equity
ROE curve from below and the operations beyond the intersection of ROIAIT by (leverage equity) $50 \%$ equity ROE as a relatively low risk high profit zone. The intersection points may vary from firm to firm/product to product/project to project or within them in between different times for the change in values of variables of operational activities and further at different levels of financial leverage or cost of debt but the principle of intersection points is universal.

Hence it reveals the varied financial risk implied zones helps to take steps either to minimise the risk or to maximise the returns through optimal change in the financial leverage in the light of changes in operational leverage and vice versa. This further reveals the financial breakeven (point of recovery of interest) at the point of intersecting the $\mathrm{X}$ axis by either ROIAIBT or ROE curves, in each of their case, apart from operating breakeven determined through ROS curve intersecting/ touching the $\mathrm{X}$ axis.

Apart from the above more importantly this innovation discloses the much relevant facts of financial equilibrium level of price and output and sales. It is identifiable at the point where the MROE intersecting the ROIAIT (100\% equity) or ROE/AROE (with leverage) curve, is a unique implication. Further this become the perfect integrative analysis for measuring the impacts of financial and operating leverages on performances, profits and profitability under changing economic environmental conditions.

This also reveals the point of intersection between the ROIAT and the ROE as the financial leverage indifference level of activity.

In consideration of the existing common economic analytical facts available in economics and managerial economics, the analysis with the innovative formulae ensures the following positive effects for decision making.

\begin{tabular}{|c|c|c|c|}
\hline Cum output \& sales units & ROIAIBT\% & $\mathbf{1 0 0} \%$ equityR0E\% & M0\% equity ROE\% \\
\hline 2000 & -2.5 & 0 & -5 \\
\hline 5000 & 1.5 & 2.4 & 1.8 \\
\hline 8000 & 5.2 & 4.62 & 48 \\
\hline 12000 & 9.74 & 7.344 & 4.24 \\
\hline 15000 & 12.16 & 8.796 & 11.688 \\
\hline 20000 & 12.03 & 8.718 & 14.592 \\
\hline
\end{tabular}

Table 12: Table contained the data for determination of optimum ROE with financial leverage optimization through effectiveness of operations by equilibrium price and output.

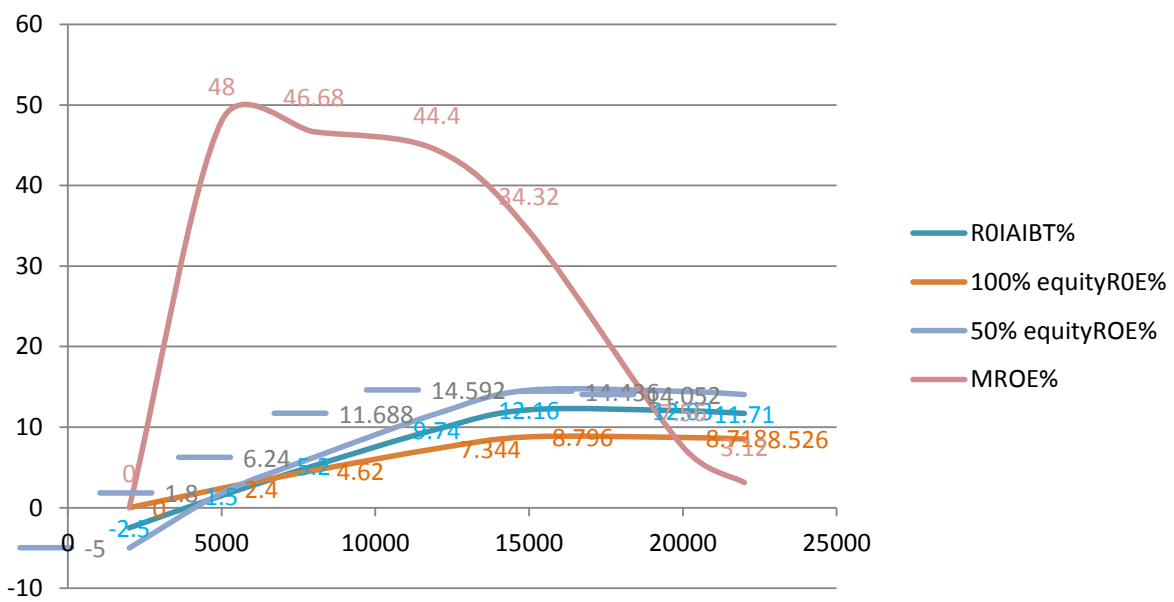

Figure 5: Graphical expression of the data of the Table 12 showing separately the optimum financial effectiveness or financial equilibrium price and output. 


\section{Positive effects of the innovation}

- The above extensions enable the BEA as an effective system of management and control through the presentation of a curve that represents the predicted economic/operational trend impacts on profits.

- This helps to determine the equilibrium rate of profit on sales and on the investments.

- It considerably reduces the dependency of the analysis on the assumptions and ensures a clear demarcation from the conventional BEA quite rightly be named as the modern approach and advance applications.

- It able to provide the results with the effects of changes in values of variables viz. values of costs, price apart from volume and including the changes in investments and leverages

- It ensures the profits attainable at maximum effectiveness under predicted dynamics of economic environments during the progress of business operations within the plan period.

- It ensures the determination of a trade-off between the sales volume and the selling price inconsideration of changes in other elements for optimization of profits through optimization of profitability is the key factor for accuracy in planning for profits.

- The substitution of rate of profit (common factor) in place of constant amount of profit in planning ensures the BEA as more effective analysis beyond the mare planning and enables to yield the desired results.

- As this helps for measurement of results in a progressive implication in accordance with the predicted market/ economic/ environmental dynamics, the BEA not only become more reliable in planning for profits but also the profitability further helps for management and control in attainment of them.

- The above formulae using together with the micro soft excel work sheet ensures much simple calculations and simplified single modern breakeven chart sufficient to provide all the information for effective decision making, management and control of operating profits and profitability.

- This can be considered as the best model that ensures the integration of operational analysis and financial analysis together with the effects of economic environmental dynamics.

- This ensures optimal integration of economic analysis with operational and financial analysis for the derivation of operational and financial equilibrium price and output and the optimization of profits and profitability on sales and on investments as a practical analytical tool for the theory of economic equilibrium price and output with financial/accounting costs.

- It reveals the responsiveness of return on equity with respect to changes in investment, capital structure and leverages together with changes in operating elements with optimal integration of financial and operating analysis.

- This innovation provides scope of optimal flexibility in using the values of variable at its realistic levels and limits in the progress of operations in the light of changes in the economic environment.

- This reveals that the proportion of breakeven sales to total sales (BEPR) is more informative and meaningful than the amount or quantity of sales for breakeven either in constant consideration or in changing environments. The curve of breakeven ratio clarifies the net impact of changes in costs, price and the volume on the position of Break Even [11].

\section{Negative side of this analysis} below

The applicable limitations of the innovative analysis are given

- The analysis needs the determination of likely changes in values of variables in accordance with the predicted economic environmental changes in intervals.

- The analysis considers the assumptions of BEA applicable within the predicted limits of volumes in continuous/discrete intervals during the plan period.

- It assumes that it is possible to determine the occurrence of changes in i.e., price, variable costs, fixed costs, investments, capital structure, the cost of debt, etc., variables at different definite stages in continuous or discrete intervals during the course of operations.

- It is difficult to apply for the organization where the prices and costs would change erratically day by. In such situations average of stipulated period may be considered at definite intervals.

\section{Conclusion}

The above hypothetical example ensures that the innovative formulations become instrumental to optimize the effectiveness of assumptions of BEA to its applicable limits from the indefinite limits (unlimited extent). The trends and practices of firms in overpowering the competition and in increasing the output and sales, it is a common aspect that the firm has to reduce the sales prices apart from increasing the fixed costs with hike on advt. and variable costs like sales force commission etc. apart from increasing/decreasing of additional material/labor etc costs. The changes in values are common phenomena for most of the organizations from one level of activity to other. Therefore, the system of analysis should be such that it can absorb all such changes and present an able and compact report for the authorities. with the above example, the innovative approach proved the successful absorption of flexibility on one hand and on the other reducing the scope of misleading implications of conventional BEA at times of deciding the additional units of output and sales at lower and lower price and higher and higher costs and vice versa. This innovation analysis can determine the optimum level of operating rate of profit on sales and rate of return on equity. A methodical expansion for determination of financial equilibrium price and output in practice as a practical application for the theoretical equilibrium price output determination by a firm under different market conditions viz. monopoly/monopolistic/oligopoly competitive firm. This is made possible through the disclosure of possibilities for determination of average/aggregate and marginal rate of profits/returns under the breakeven concept in practice with simple calculations. Further it enables to provide the graphical application enabling to present the graph that compatible with the economic trend effects of changing values of the variables viz. price, costs, volume and the level of investments in-tune with the economic theory of equilibrium. Unlike the conventional BEA this helps to compare the predictions with that of the actual and helps for timely decisions in managing and controlling while facing the competition and understanding the impact of the tendencies of the environment on profits/earning and profitability.

Though the innovative analysis consists of few limitations, in 
Citation: Chandra RS, Banana K (2017) Operating and Financial Equilibrium: A Perfect Solution for Price Output Determination Irrespective of Competition. J Bus Fin Aff 6: 284. doi: 10.4172/2167-0234.1000284

the light of ways and means available to overcome them and results it provides for the questions "What-If" Analysis versus Changing the Model for decision making apart from planning with the disclosure of natural economic principle of equilibrium points in financial analysis, it is a perfect solution for unresolved sensitive and vital areas of financial decision making problems such as perfection in determination of operating and financial leverages and related areas.

\section{Declaration}

I solemnly declare that the above is a sheer intuitive thought of the author and nothing is copied in the parts of the above innovative formulations and analysis, except the generalizations cited and the references cited and the stated content adopted. If you found the same anywhere in the past, it is purely due to non-accessibility to such work, kindly give the details of that work(s), if possible/necessary and they duly regarded. Your cooperation in this regard is earnestly solicited.

Your comments and suggestions are earnestly solicited.

\section{References}

1. Jain SP, Narang KL (2011) Cost accounting principles and practice. 22nd Revised Edition, Kalyani publishers.

2. Arora MN (2010) A Textbook of Cost and Management Accounting. (10 ${ }^{\text {th }}$ edn.), Vikas Publishing.
3. Chandra P (2002) Projects: Planning, analysis, selection, financing implementation, and review. (7th edn), CFM-TMH professional series in finance.

4. Colin Drury (2016) Management and cost accounting. (6 ${ }^{\text {th }}$ edn.), Cengage learning India edition.

5. Chandra SR, Banana K (2016) Innovative Formulations and Enhanced Scope of Break Even Analysis. IRJBM 9: 1.

6. Chandra SR, Banana K (2016) Innovative Formulations and Enhanced Additional Applications of Break Even Analysis. IRJBM 9: 5.

7. Chandra SR, Banana K (2016) Karivena Effects in Application of Breakeven Analysis for Strategic Pricing Advanced Applications in Breakeven Applications. IJMB 4: 232-239.

8. Chandra SR, Banana K (2015) Innovations in Measuring the Impact and Action Recourse for Changes in Costs Prices Product Mix and Volume on Profits, developed as an Effective Mathematical Tool for Reporting and Decision Making by Interlinking the Economic Analysis and Financial Analysis through Breakeven Analysis.

9. Chandra SR, Banana K (2016) Risk Management System Implementation: Improving the Role of Internal Control Unit (SPI).

10. Martin JR (Not dated) Conventional Linear Cost-Volume-Profit Analysis Management Accounting: Concepts, Techniques \& Controversial Issues. Management and Accounting Web.

11. Martin JR (Not dated) Investment Centers, Return on Investment, Residual Income and Transfer Pricing. Management Accounting: Concepts, Techniques \& Controversial Issues. Management and Accounting Web. 